\title{
Detection of Trypanosoma cruzi strains circulating in Córdoba department (Colombia) isolated from triatomines (Hemiptera: Reduviidae) collected by the community
}

\author{
Cielo León', Mario Iván Ortiz¹, Catalina Tovar², Jorge Negrete², Ernesto Arroyo², \\ Camila González ${ }^{1}$ \\ ${ }^{1}$ Centro de Investigaciones en Microbiología y Parasitología Tropical, CIMPAT, Departamento de \\ Ciencias Biológicas, Universidad de los Andes, Bogotá, D.C., Colombia \\ ${ }^{2}$ Grupo de Enfermedades Tropicales y Resistencia Bacteriana, Universidad del Sinú, Montería, \\ Colombia
}

Introduction: From 2011 to 2016, 24 cases of Chagas disease were reported in Córdoba according to the national public health surveillance system (Sistema Nacional de Vigilancia en Salud Pública, Sivigila), but the information regarding Trypanosoma cruzi circulating strains and infection rates are unknown.

Objectives: To establish the triatomine species with which people come in contact and recognize as Chagas disease vectors, as well as to assess the infection with trypanosomes and make an exploratory approach to host feeding preferences with the participation of the local community.

Materials and methods: Triatomines sampling was conducted in 12 municipalities between 2011 and 2016; T. cruzi infection was established by k-PCR, SAT-PCR, while strain genotyping was done by mini-exon and SL-IR (spliced-leader intergenic region) sequence characterization. We also screened for blood sources.

Results: Local community members collected the majority of triatomines and we identified three species: Rhodnius pallescens, Panstrongylus geniculatus, and Eratyrus cuspidatus. The overall $T$. cruzi infection rate in collected triatomines was $66.6 \%$ and we detected the $\mathrm{Tcl}_{\mathrm{DOM}}$ and Tcl sylvatic strains. Community-based insect collection allowed reporting the presence of $P$. geniculatus in two new disperse rural settlements, $T$. cruzi infection of $P$. geniculatus in Córdoba, and the first report of triatomines infected with T. cruzi in Montería municipality.

Received: $11 / 07 / 17$

Accepted: $17 / 09 / 18$

Published: 18/09/18

Citation:

León C, Ortiz MI, Tovar C, Negrete J, Arroyo E, González C. Detection of Trypanosoma cruzi strains circulating in Córdoba department (Colombia) isolated from triatomines (Hemiptera: Reduviidae) collected by the community. Biomédica. 2019;39:265-77. https://doi.org/10.7705/biomedica.v39i2.3973

Corresponding author:

Cielo León, Centro de Investigaciones en Microbiología y Parasitología Tropical, Universidad de los Andes, Carrera 1 № 18A - 12, bloque A, segundo piso, Bogotá, D.C., Colombia

Telephone: (571) 339 4949, extension 3395

cm.leon@uniandes.edu.co

\section{Author contributions:}

Cielo León: Molecular analysis and manuscript preparation

Mario Iván Ortiz: Triatomines identification, data analysis, and manuscript preparation

Jorge Negrete and Ernesto Arroyo: Specimen

collection and community work

Catalina Tovar: Specimens collection and study design

Camila González: Study design, data analysis, and manuscript preparation

Funding:

Sistema General de Regalías, Colombia, contract number 754-2013 and Gobernación de Córdoba

Conflicts of interest:

There are no conflicts of interest.
Conclusions: These results revealed the presence of triatomines infected with $T$. cruzi inside dwellings in five municipalities of Córdoba. The dominant circulating T. cruzi strain was $\mathrm{TCl}_{\mathrm{DOM}}$, a genotype associated with human Chagas disease and cardiomyopathies in Colombia. Our results highlight the importance of local community participation in entomological surveillance tasks.

Keywords: Trypanosoma cruzi; Chagas disease; Rhodnius; Panstrongylus; Reduviidae; Triatominae.

Detección y caracterización molecular de cepas de Trypanosoma cruzi aisladas de triatominos recolectados por la comunidad en el departamento de Córdoba, Colombia

Introducción. Entre el 2011 y el 2016, se reportaron 24 casos de enfermedad de Chagas en Córdoba, según el Sistema Nacional de Vigilancia en Salud Pública (Sivigila), pero la información sobre las unidades discretas de tipificación de Trypanosoma cruzi circulantes y las tasas de infección se desconoce.

Objetivos. Identificar las especies de triatominos con las cuales las personas entran en contacto y que reconocen como vectores de la enfermedad de Chagas, así como establecer la infección por tripanosomas y explorar posibles fuentes de alimentación de los triatominos con la participación de la comunidad.

Materiales y métodos. El muestreo de triatominos se hizo en 12 municipios entre el 2011 y el 2016. T. cruzi se detectó mediante las técnicas de kinetic-polymerase chain reaction (k-PCR) y serial amplification of targets-polymerase chain reaction (SAT-PCR), en tanto que la genotipificación de las cepas se logró mediante la caracterización de secuencias de genes miniexon y de la región intergénica SL-IR (Spliced-Leader Intergenic Region). Se evaluaron, asimismo, las fuentes de alimento.

Resultados. La mayoría de los triatominos fue recolectada por miembros de la comunidad y se identificaron tres especies: Rhodnius pallescens, Panstrongylus geniculatus y Eratyrus cuspidatus. La tasa de infección general por T. cruzi fue de $66,6 \%$ y se detectaron las cepas $\mathrm{Tcl}_{\text {Dom }}$ y Tcl sylvatic. La participación de la comunidad permitió reportar la presencia de $P$. geniculatus en dos nuevas localidades, la infección con $T$. cruzi de $P$. geniculatus en 
Córdoba y reportar por primera vez triatominos infectados con T. cruzi en Montería. Conclusiones. Se demostró la presencia de triatominos infectados con $T$. cruzi dentro de las viviendas en cinco municipalidades. La cepa circulante dominante fue $T$. cruzi $\mathrm{Tcl}_{\mathrm{Dom}}$, asociada con la enfermedad de Chagas y con cardiomiopatías en Colombia. Los resultados resaltan la importancia de vincular a miembros de la comunidad en la vigilancia entomológica.

Palabras clave: Trypanosoma cruzi; enfermedad de Chagas; Rhodnius, Panstrongylus; Reduviidae; Triatominae.

Chagas disease (CD) is caused by the parasite Trypanosoma (Schizotrypanum) cruzi (1), and mainly transmitted by blood-sucking vectors of the Reduviidae family. This disease is considered unattended and a serious public health problem in Latin America (2) due to the number of persons at risk and the lack of adequate and accessible treatment (3).

Trypanosoma cruzi exhibits a broad intraspecific genetic diversity and is classified into six discrete typing units (DTUs) identified from Tcl to TcVI $(4,5)$. Tcl presents the broadest geographical distribution, which covers from the southern United States of America to northern Argentina and Chile. This DTU can be found in the sylvatic and domestic transmission cycles (5-7) and is known to infect 150 species belonging to 24 families of domestic and wild animals (8).

The main vectors of $T$. cruzi in the Andean region, the southern cone, and some areas of Central America are: Rhodnius prolixus, Triatoma dimidiata, Triatoma infestans, and Panstrogylus megistus (9). A total of 26 species has been reported in Colombia and 15 of them have been found naturally infected with $T$. cruzi. R. prolixus, and $T$. dimidiata are considered primary vectors, whereas Panstrogylus geniculatus, Triatoma maculata, Rhodnius pictipes, and Rhodnius pallescens are considered secondary vectors (8).

In Colombia, the prevalence of Chagas disease has been estimated between 700,000 and $1,200,000$ infected people and 3,500,000 people at risk (10). The Andean region is the most densely populated of the country and it harbors the municipalities with the highest Chagas disease transmission risk followed by the Orinoquia region $(8,11)$. The departments with the highest infection rates are Arauca (21.1\%), Casanare (10\%), Santander (6.3\%), Norte de Santander (5.2\%), Boyacá (3.7\%), Cundinamarca (1.9\%), and Meta (1.7\%) (11).

However, it is important to mention that as a neglected tropical disease, and due to the delay in the time of appearance of clinical symptoms (that can be diagnosed after 40 years of infection), the prevalence and incidence of Chagas disease are highly underestimated due to case underreport (12).

In the Caribbean coast, at least one case of the disease has been reported in every department (13-15). The known vectors found infected with $T$. cruzi are $R$. prolixus, T. maculata, T. dimidiata, R. pallescens, and Eratyrus cuspidatus, which are distributed in seven departments there (8).

The department of Córdoba is located north of Colombia on the Caribbean plains between $09^{\circ} 26^{\prime} 16^{\prime \prime}$ and $07^{\circ} 22^{\prime} 05^{\prime \prime} \mathrm{N}$, and $74^{\circ} 47^{\prime} 43^{\prime \prime}$ and $76^{\circ} 30^{\prime} 01^{\prime \prime} \mathrm{W}$, with an altitude between 260 and 2,200 m.a.s.I. It has 1,709,644 inhabitants distributed over an approximate total area of $23,980 \mathrm{~km}^{2}$, with a climate that goes from semi-wet to arid, and it includes 30 municipalities (16).

There are three main types of ecosystems in Córdoba: savannas, forests, and aquatic (marine and freshwater) systems. These ecosystems form a tropical wet biome with a high variety of native flora and fauna (17). Such diversity makes it suitable for the presence of Chagas disease vectors and 
reservoirs and for the establishment of different cycles of Chagas disease transmission. Furthermore, Córdoba socioeconomic characteristics favor the establishment of the disease, especially poverty (46.6\%) and extreme poverty (12.9\%), and a Gini coefficient of 0.465 (18).

The main vector species in Córdoba is $R$. pallescens, which has been reported naturally infected with $T$. cruzi and $T$. rangeli in this region (8). Panstrongylus geniculatus and E. cuspidatus have also been reported. There is no information on $P$. geniculatus infection for this region so far, while $E$. cuspidatus has been reported naturally infected with $T$. cruzi (8). Between 2012 and 2016, 20 cases of Chagas disease were reported in Córdoba by the Sistema Nacional de Vigilancia en Salud Pública (Sivigila) with an average of 4.2 cases per year (15) (figure 1).

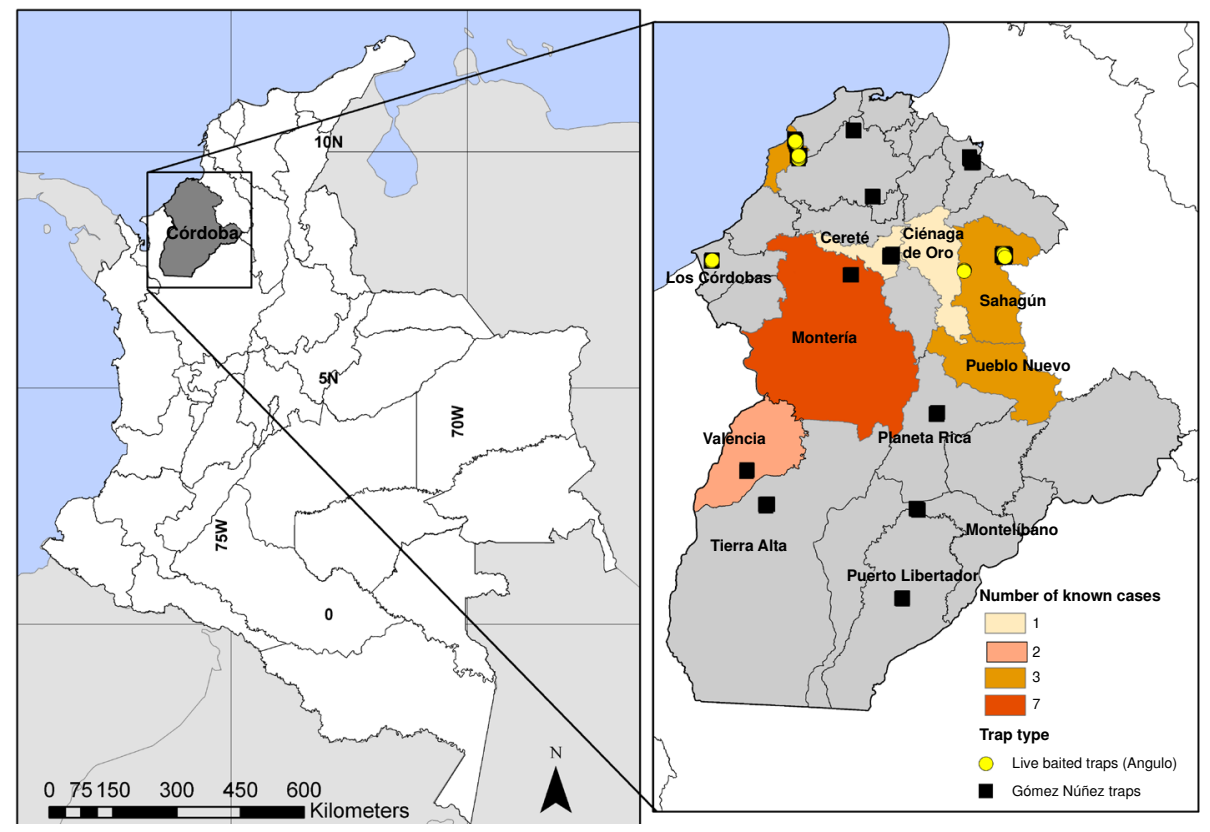

Figure 1. Location of Córdoba department in Colombia and distribution of municipalities and dispersed rural settlements (veredas) where sampling was performed. Chagas disease cases distribution by municipality (2012-2016) is also shown. In each of the 24 houses visited per dispersed rural settlement, two Gómez-Núñez traps were placed. Additionally, Angulo traps were placed in five dispersed rural settlements.

Regarding the entomological surveillance of the disease, community participation has proven to be the most appropriated strategy to develop a sustainable, effective, and efficient Chagas disease prevention program (19). An essential aspect to achieve this participation is that community members that interact with triatomines recognize them as Chagas disease vectors (19). Dumonteil, et al. (20) demonstrated that community-based collection was the most sensitive and cost-effective method as compared with timed manual searches for monitoring domestic and peridomestic infestation by nondomiciliated triatomines (20).

Due to the low number of cases occurring in Córdoba, little is known regarding vectors involved in Chagas disease transmission and circulating parasite strains. In 2011, the program "Diseño de un programa de estudios en infecciones y salud tropical para el departamento de Córdoba" received funds from the Sistema General de Regalías (general system of royalties) to determine the baseline for the study of tropical neglected diseases in the department. 
In the context of this project, the aim of this study was to establish the triatomine species with which people come in contact and recognize as Chagas disease vectors, their infection with trypanosomes, and the insects host feeding preferences with the participation of local community members. Our results put in evidence that Chagas disease is present in Córdoba and contributed new records of triatomine insects, their spatial distribution, their infection with different $T$. cruzi strains, and information on their food sources in order to provide health authorities with relevant information for decisionmaking regarding tropical neglected diseases in the department of Córdoba.

\section{Materials and methods}

\section{Insect collection}

As a part of the above-mentioned program, fieldwork was performed in 12 municipalities and 15 dispersed rural settlements in Córdoba, Colombia, where 24 houses were randomly selected to conduct sampling of hematophagous insects. For triatominae screening, two Gómez-Núñez traps (21) were placed inside each of the 24 houses selected in each settlement from 2011 to August, 2016. The traps were checked for the presence of triatomines once a month.

Since triatominae collection in urban settings is challenging, we first visit each municipality to educate people on the importance of Chagas disease and to ask if they had seen triatomine bugs inside their houses. In three municipalities (Los Córdobas, Sahagún, and Moñitos), where human cases had been reported during the time of the study, we provided collection jars to the dwellers after explaining the general aspects of the disease and the risk of vector transmission and people were asked to deliver all collected specimens to the local health authorities.

A total of 96 houses were initially included for community sampling and, finally, triatomines were obtained from 45 houses. In each municipality, one inhabitant was designated to gather the insects obtained from different houses, to record the information, and to deliver the insects to the health authorities once a month.

Collected insects were then delivered to Universidad del Sinú to perform parasite detection in the rectal ampulla by dissection and then to the Centro de Investigaciones en Microbiología y Parasitología Tropical, CIMPAT at Universidad de Los Andes, where species identification and molecular analyses were performed.

Additional sampling with Angulo traps was performed in the three municipalities where collection jars were provided (22). In Moñitos, two Angulo traps were placed in palm trees on the night of May 12, 2015 (09'14'45.9" N, 76004' 54.6" W, 79 m.a.s.I.). In Sahagún dispersed rural settlements of Salitral (June 28 to July 1, 2016) and Villa Lucía (August 8 to 11, 2016), and in Los Córdobas and Guaimaro Abajo (August 1 to 3,2016), three traps were placed during three consecutive nights in different species of palm trees around houses where infection had been presumably acquired (figure 1).

Collected specimens were identified by external morphological characters using Lent and Wygodzinsky taxonomic key (23) and Weirauch, et al., illustrated key (24). 


\section{Parasite detection}

To perform parasite detection and blood meal analyses using molecular methods, DNA was extracted from triatomine intestinal content using the High Pure PCR Template Preparation Kit ${ }^{\mathrm{TM}}$ (Roche, USA) following manufacturer instructions.

Parasite detection by k-PCR was performed through amplification of a kinetoplastid DNA sequence with PCR using the 121 (5'AAATAATGTACGGGKGAGATGCATGA 3') and 122 (5' GGTTCGATTGGGGTTGGTGTAATATA 3') primers (25) in a final volume of $25 \mu \mathrm{L}$ containing $1 X$ Go Taq Green Master Mix M7123 ${ }^{\text {TM }}$ (Promega, USA), $0.5 \mu \mathrm{M}$ of each primer, and $3 \mu \mathrm{L}$ of DNA.

The thermal profile consisted of an initial denaturation at $94^{\circ} \mathrm{C}$ for $3 \mathrm{~min}$ followed by 5 cycles at $94^{\circ} \mathrm{C}$ for $1 \mathrm{~min}$, annealing for $1 \mathrm{~min}$ at $68^{\circ} \mathrm{C}$ and 1 min at $72^{\circ} \mathrm{C}$, then 35 cycles at $94^{\circ} \mathrm{C}$ for $45 \mathrm{~s}$, annealing for $45 \mathrm{~s}$ at $64^{\circ} \mathrm{C}$ and $45 \mathrm{~s}$ at $72^{\circ} \mathrm{C}$ followed by a final extension step at $72^{\circ} \mathrm{C}$ for $10 \mathrm{~min}$. The PCR products were resolved by $2 \%$ agarose gel electrophoresis and stained with SYBR Safe ${ }^{\text {TM }}$ (Invitrogen, Ref. S33102) generating a product with a length of $330 \mathrm{bp}$ for $T$. cruzi and of 400-450 bp for $T$. rangeli.

According to the diagnostic algorithm for T. cruzi (26), the k-PCR results were confirmed with an SAT-PCR assay as follows: A satellite DNA sequence was amplified with PCR using the Cruzi 1 (5' ASTCGGCTGATCGTTTTCGA 3') and Cruzi 2 (5' AATTCCTCCAAGCAGCGGATA 3') primers (27) in a final volume of $25 \mu \mathrm{L}$ containing $1 X$ Go Taq Green Master Mix M7123 ${ }^{\mathrm{TM}}$ (Promega, USA) and $0.5 \mu \mathrm{M}$ of each primer and $3 \mu \mathrm{L}$ of DNA.

The thermal profile consisted of an initial denaturation at $94^{\circ} \mathrm{C}$ for $5 \mathrm{~min}$ followed by 40 cycles at $94^{\circ} \mathrm{C}$ for $1 \mathrm{~min}$, annealing for $30 \mathrm{~s}$ at $64^{\circ} \mathrm{C}$ and for $1 \mathrm{~min}$ at $72^{\circ} \mathrm{C}$. The PCR products were resolved by $2 \%$ agarose gel electrophoresis and stained with SYBR Safe ${ }^{\mathrm{TM}}$ (Invitrogen, Ref. S33102) generating a product with a length of $166 \mathrm{bp}$ for T. cruzi.

\section{Genotyping}

To perform T. cruzi molecular genotyping, the mini-exon gene was amplified with PCR using the TCC (5' CCCCCCTCCCAGGCCACACTG 3'), TC1M (5' GTGTCCGCCACCTCCTTCGGGCC 3') and TC2 (5' CCTGCAGGCACACGTGTGTGTG 3') primers (28) in a final volume of $25 \mu \mathrm{L}$ containing $1 X$ Go Taq Green Master Mix M7123 ${ }^{\mathrm{TM}}$ (Promega, USA), $0.5 \mu \mathrm{M}$ of each primer, and $3 \mu \mathrm{L}$ of DNA.

The thermal profile consisted of an initial denaturation at $94^{\circ} \mathrm{C}$ for $5 \mathrm{~min}$ followed by 5 cycles at $94^{\circ} \mathrm{C}$ for $1 \mathrm{~min}$, annealing for $1 \mathrm{~min}$ at $67^{\circ} \mathrm{C}$ and $1 \mathrm{~min}$ at $72^{\circ} \mathrm{C}$, then 5 cycles at $94^{\circ} \mathrm{C}$ for $1 \mathrm{~min}$, annealing for $1 \mathrm{~min}$ at $65^{\circ} \mathrm{C}$ and 1 min at $72^{\circ} \mathrm{C} ; 5$ cycles at $94^{\circ} \mathrm{C}$ for $1 \mathrm{~min}$, annealing for $1 \mathrm{~min}$ at $63^{\circ} \mathrm{C}$ and for 1 min at $72^{\circ} \mathrm{C}$, and 30 cycles at $94^{\circ} \mathrm{C}$ for $1 \mathrm{~min}$, annealing for $1 \mathrm{~min}$ at $61^{\circ} \mathrm{C}$ and for $1 \mathrm{~min}$ at $72^{\circ} \mathrm{C}$ followed by a final extension step at $72^{\circ} \mathrm{C}$ for $10 \mathrm{~min}$. The PCR products were resolved by $2 \%$ agarose gel electrophoresis and stained with SYBR Safe ${ }^{\mathrm{TM}}$ (Invitrogen, Ref. S33102), generating a product with a length of $350 \mathrm{bp}$ for Tcl and $300 \mathrm{bp}$ for Tcll.

An SL-IR (spliced-leader intergenic region) sequence was amplified with PCR using the 1 Am (5' TGTGTGTGTATGTATGTG 3') (29) and the 1 B (5' CGGAGCGGTGTGTGCAG 3') primers (30) in a final volume of $20 \mu \mathrm{L}$ containing 1X Buffer Taq ${ }^{\mathrm{TM}}$ (Invitrogen, USA), $0.25 \mathrm{mM}$ of each dNTP, 1.5 
$\mathrm{mM} \mathrm{MgCl}, 2,5 \mu \mathrm{M}$ of each primer, 1 unit of Taq DNA polymerase (Invitrogen, USA), and $3 \mu \mathrm{L}$ of DNA.

The thermal profile consisted of an initial denaturation step at $94^{\circ} \mathrm{C}$ for 4 min followed by 35 cycles at $94^{\circ} \mathrm{C}$ for $30 \mathrm{~s}, 20 \mathrm{~s}$ at $55^{\circ} \mathrm{C}$, and $30 \mathrm{~s}$ at $72^{\circ} \mathrm{C}$ with a final extension at $72^{\circ} \mathrm{C}$ for $10 \mathrm{~min}$. The PCR products were resolved by $2 \%$ agarose gel electrophoresis and stained with SYBR ${ }^{\text {TM }}$ Safe (Invitrogen, Ref. S33102) generating a product with a length of $231 \mathrm{bp}$ for $\mathrm{TCl}_{\mathrm{DOM}}$ and 450$550 \mathrm{bp}$ for Tcl sylvatic.

\section{Blood source detection}

A PCR-based blood source detection was performed using the primers for the cytochrome $b$ gene previously described (31). For detection of avian-derived blood source, the PCR was first conducted with the primers Avian-3 (5' GACTGTGAYAAAATYCCMTTCCA 3') and Avian-4 (5'GYCTTCAITYTTTGGYTTACAAGAC 3') followed by a nested PCR with Avian-3 and Avian-8 (5' TCTTTGGTTTACAAGACCAATGTTT 3'). For mammalian derived blood source, the PCR was first conducted with primers Mammalian-1 (5' TGAYATGAAAAAYCATCGTTG 3') and Mammalian-2 (5' TGTAGTTRTCWGGGTCKCCTA 3') and followed by nested PCR with Mammalian-2 and Mammalian-7 (5' AAAAACCATCGTTGTATTTCAACTA 3').

The PCRs were performed in a final volume of $25 \mu \mathrm{L}$ containing $1 \times$ Go Taq Green Master Mix M7123 ${ }^{\mathrm{TM}}$ (Promega, USA), $0.5 \mu \mathrm{M}$ of each primer, and $3 \mu \mathrm{L}$ of DNA.

The thermal profile consisted of an initial denaturation at $94^{\circ} \mathrm{C}$ for 2 min followed by 35 cycles at $94^{\circ} \mathrm{C}$ for $30 \mathrm{sec}$, annealing for $30 \mathrm{sec}$ at $55^{\circ} \mathrm{C}$ and for $1 \mathrm{~min}$ at $72^{\circ} \mathrm{C}$, and a final extension step at $72^{\circ} \mathrm{C}$ for $4 \mathrm{~min}$. The PCR products were resolved by $2 \%$ agarose gel electrophoresis and stained with SYBR Safe ${ }^{\mathrm{TM}}$ (Invitrogen ${ }^{\mathrm{TM}}$ Ref. S33102) generating a product with a length of $530 \mathrm{bp}$ for avian blood sources and $810 \mathrm{bp}$ for mammalian blood sources.

All PCR positives products were bidirectionally sequenced at the DNA sequencing laboratory of Universidad de Los Andes using the ABI-3500 Genetic Analyzer TM (Life Technologies).

\section{Results}

\section{Insect collection}

In total, 46 insects were collected, $45(97.8 \%)$ by community members from five municipalities and one (2.1\%) was captured using Angulo traps. No insects inside the houses were collected with Gómez-Núñez traps. All the collected specimens belonged to order Hemiptera, 37 to subfamily Triatominae, tribes Rhodniini and Triatomini, five to Reduviidae no Triatominae (predators), and four non Reduviidae (phytophagous) (table 1).

From 37 collected Triatominae, 34 were identified as belonging to three species: $R$. pallescens, $P$. geniculatus, and E. cuspidatus. In the remaining three, species identification wasn't performed due to the damage of specimens during transport. Rhodnius pallescens was the species with the largest number of captured individuals (23) followed by $P$. geniculatus with 10 and $E$. cuspidatus with 1 . From these 34 identified specimens, 31 were adults and 3 were nymphal instars. Out of the 37 collected triatomines, $36(97.3 \%)$ were collected in dwellings at night and only one (2.7\%), a nymphal instar, was collected in the peridomicile. 
Table 1. Species of triatomines collected in Córdoba

\begin{tabular}{lrrrrr}
\hline Triatomine species & \multicolumn{7}{c}{$\begin{array}{c}\text { Number of triatomine/municipaly (\%) } \\
\text { nonitos }\end{array}$} & $\begin{array}{c}\text { Sahagún } \\
\mathbf{n} \%\end{array}$ & $\begin{array}{c}\text { Los Córdobas } \\
\mathbf{n} \%\end{array}$ & $\begin{array}{c}\text { Cotorra } \\
\mathbf{n} \%\end{array}$ & $\begin{array}{c}\text { Montería } \\
\mathbf{n} \%\end{array}$ \\
\hline Rhodnius pallescens & $14(33.3)$ & $8(19)$ & $1(2.4)$ & $0(0)$ & $0(0)$ \\
Panstrongylus geniculatus & $7(16.6)$ & $1(2.4)$ & $1(2.4)$ & $1(2.4)$ & $0(0)$ \\
Eratyrus cuspidatus & $0(0)$ & $0(0)$ & $0(0)$ & $0(0)$ & $1(2.4)$ \\
Damaged specimens & $1(2.4)$ & $2(4.8)$ & $0(0)$ & $0(0)$ & $0(0)$ \\
Reduviidae no Triatominae & $1(2.4)$ & $4(9.5)$ & $0(0)$ & $0(0)$ & $0(0)$ \\
Total & 23 & 15 & 2 & 1 & 1 \\
\hline
\end{tabular}

The triatomines were sent from five municipalities: Sahagún, Moñitos, Los Córdobas, Cotorra, and Montería (these two last municipalities were not previously included for community sampling, but two specimens were sent to the health authorities during the present study). The highest number of insects was captured in Moñitos (22 individuals) followed by Sahagún (11), Los Córdobas (2) Cotorra (1), and Montería (1) (figure 2).

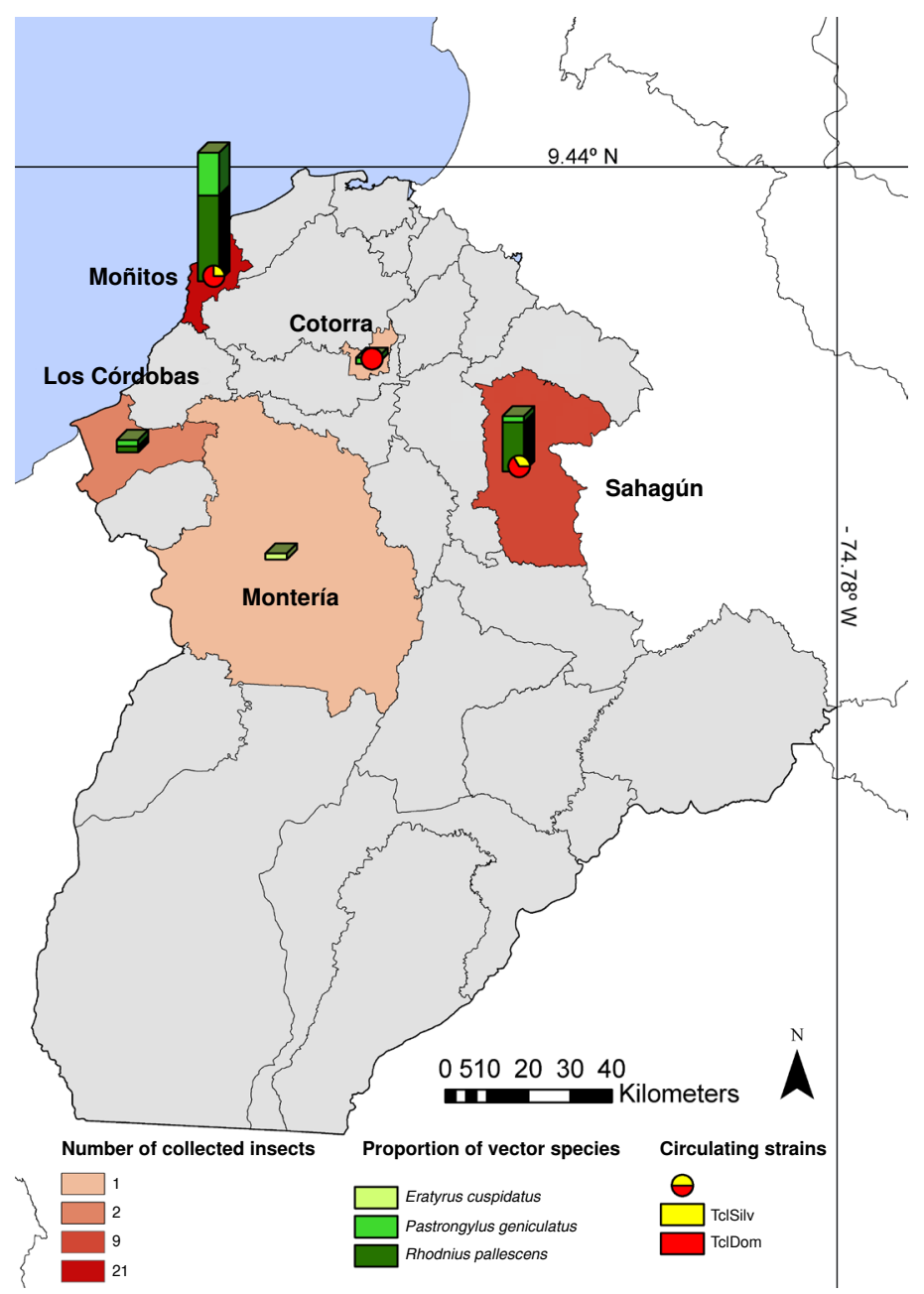

Figure 2. Municipalities where triatomine bugs were collected showing total number of collected insects, proportion of triatomine species, and Trypanosoma cruzi circulating strains 


\section{Parasite detection}

Eighteen triatomines were processed to establish possible infection by trypanosomes using PCR: Four were negative, 13 were positive for $T$. cruzi, and one for $T$. rangeli. From the $13 T$. cruzi positive individuals, seven were $R$. pallescens, three $P$. geniculatus, and one E. cuspidatus. The remaining two specimens could not be identified due to the damage of taxonomic characters during transport. The insect infected with $T$. rangeli was identified as $R$. pallescens.

\section{Genotyping}

Genotyping showed that all the $T$. cruzi positive insects belonged to the Tcl genotype. Nine were infected with the genotype T. cruzi Tcl ${ }_{\mathrm{DoM}}$ : $\operatorname{six} R$. pallescens (five from Moñitos and one from Sahagún), two $P$. geniculatus (one from Moñitos and one from Cotorra), and one specimen that could not be identified from Moñitos. The remaining infected insects had Tcl sylvatic genotype: One $R$. pallescens, another specimen that could not be identified from Moñitos, and one P. geniculatus from Sahagún (figure 2, table 2).

Table 2. Genotyping of Tripanosoma cruzi detected in triatomines

\begin{tabular}{|c|c|c|c|c|c|c|}
\hline \multirow{2}{*}{ Municipality } & \multirow{2}{*}{ Triatomine species } & \multicolumn{3}{|c|}{ Trypanosoma cruzi Tcl } & \multirow{2}{*}{$\begin{array}{l}\text { Trypanosoma } \\
\text { rangeli }\end{array}$} & \multirow{2}{*}{ Negative } \\
\hline & & $\mathrm{Tcl}_{\text {DoM }}$ & Tcl sylvatic & Unidentified* & & \\
\hline \multirow[t]{2}{*}{ Moñitos } & Rhodnius pallescens & 5 & 1 & & & \\
\hline & Unidentified damaged specimens & 1 & 1 & & & \\
\hline \multirow[t]{2}{*}{ Sahagún } & Rhodnius pallescens & 1 & & & 1 & 3 \\
\hline & Unidentified damaged specimens & & & & & 1 \\
\hline Cotorra & Panstrongylus geniculatus & 1 & & & & \\
\hline Montería & Eratyrus cuspidatus & & & 1 & & \\
\hline
\end{tabular}

* Unidentified genotype as no genotypification was done.

\section{Blood source detection}

From 37 triatomine insects, 13 had blood and all these were processed. For these 13 insects, it was possible to establish the blood source in six of them using only conventional PCR; of the five $R$. pallescens specimens, three were positive for mammalian blood and two for both mammalian and avian blood, while one $P$. geniculatus insect was positive for mammalian blood. No sequence was obtained for any of the samples.

\section{Discussion}

Most of the collected triatomines (80.5\%) corresponded to species known as Chagas vectors. The three species detected, $R$. pallescens, $P$. geniculatus, and $E$. cuspidatus, have been previously reported in the department of Córdoba (8). Rhodnius pallescens was the most abundant species (62.2\%) followed by $P$. geniculatus (27\%) and E. cuspidatus (2.7\%). These findings are consistent with the few reports known for this region that show $R$. pallescens as the predominant species (8). Most of the $R$. pallescens specimens were collected in two previously reported municipalities, Moñitos and Sahagún, and only one individual was captured in Los Córdobas municipality. 
In total, ten specimens of $P$. geniculatus were collected. Most of the specimens (seven) were collected in Moñitos. One specimen was collected in each of the following dispersed rural settlements: Sahagún, Cotorra, and Los Córdobas. This species had been previously reported in Moñitos and Sahagún (8), but it is the first time it has been reported in Cotorra and Los Córdobas. New records for two municipalities of the department were a $P$. geniculatus specimen collected in Cotorra municipality and one collected in Los Córdobas.

The species E. cuspidatus has been previously reported in Córdoba, but only in the municipality of Buenavista (8); in the present study, one specimen was collected in Montería. This is the first time that the presence of triatomines in Montería has been reported.

Three municipalities where triatomines were found (Sahagún, Cotorra, and Montería) have a savannah ecosystem. Two municipalities (Moñitos and Los Córdobas) have a coastal ecosystem (32). It is interesting to note that Sahagún is characterized by a dry environment and the presence of plant associations formed by palm trees, especially Attalea butyracea (32). The presence of palm trees may facilitate the establishment of triatomines in dwellings in this municipality. In a different palm tree species, Cocos nucifera, one nymphal instar of $R$. pallescens was collected using Angulo traps in Moñitos municipality.

In the present study, the majority of the triatomines (89.1\%) were collected in two municipalities, Moñitos and Sahagún. Most of the insects in these two municipalities were captured indoors. However, no sign of domiciliation was evident, as was shown by the absence of insects in the Gómez-Núñez traps. Three Chagas cases have been reported in each of these two dispersed rural settlements between 2012 and 2016 (15), which represent $30 \%$ of the reported Chagas cases for the department.

Seven Chagas cases have been reported in Montería in the last five years. This is the municipality with the highest number of cases (33\%) (15). However, the presence of triatomines had not been reported previously. In the present study, one E. cuspidatus infected with $T$. cruzi was collected and it is the first report of triatomines presence in this municipality.

The overall infection rate of $T$. cruzi among processed triatomines was $72 \%(13 / 18)$. The infection rate for $R$. pallescens was $64 \%(7 / 11)$, for P. geniculatus it was $100 \%(3 / 3)$, and for E. cuspidatus, $100 \%(1 / 1)$ (the remaining two $T$. cruzi positive specimens were not identified due to damage of the specimens). These indexes demonstrate that people in these areas are at high risk of $T$. cruzi infection, especially having in mind that most of the triatomines, $97.3 \%(36 / 37)$, were found by community members in their dwellings. Two new reports of natural infection for the department of Córdoba were recorded in this study: one $P$. geniculatus infected with $T$. cruzi and one $R$. pallescens infected with $T$. rangeli.

All collected insects positive for infection with trypanosomes presented T. cruzi DTU Tcl, except for one that was positive for infection with $T$. rangeli. Currently, $T$. cruzi is recognized as a complex of six lineages or DTUs named Tcl to TcVI $(4,33)$. Each DTU can be loosely associated with a particular ecological and/or geographical framework. Tcl has been found from Argentina to the United States, while Tcll to $\mathrm{VI}$ are distributed from the Amazon basin to the south of Argentina $(33,34)$. Nevertheless, it is possible to find regions where all DTUs are present, as it is the case of Colombia, where Tcl has been predominantly reported while Tcll, TcIII, TcIV, and TcVI have been reported in a low proportion (34). 
TcI DTU is ubiquitous among arboreal sylvatic foci throughout the geographic distribution of $T$. cruzi. It is the major DTU associated with Chagas disease in humans and cardiomyopathies in northern South America $(33,35)$. Several molecular tools now identify substantial genetic diversity within Tcl; these new approaches consistently reveal the presence of a genetically divergent and homogeneous Tcl group, currently called $\mathrm{Tcl}_{\mathrm{DOM}}$, and a second Tcl group called sylvatic genotype $(33,35)$.

In the present study, from 11 triatomines positive for T. cruzi Tcl infection, nine were infected with the genotype $\mathrm{Tcl}_{\mathrm{DOM}}$. This conclusion is supported by recent findings where the circulation of $\mathrm{Tcl}_{\mathrm{DOM}}$ is emerging in Colombia. In this study, sylvatic Tcl was observed in $48 \%$ and $\mathrm{Tcl}_{\mathrm{DOM}}$ in $52 \%$ of the isolates, concluding that this genotype is still adapting to the domestic cycle of transmission (36).

The remaining two T. cruzi Tcl infected insects presented the Tcl sylvatic genotype. This genotype is associated with the sylvatic cycle and with the peridomestic cycle of Chagas disease in Colombia. It has been isolated from synanthropic reservoirs like Didelphis marsupialis and Rattus rattus (35). In this study, feeding preferences were determined in six triatomines. All of them had fed on mammalian blood and two of them had also fed on avian blood. It was not possible to establish the mammalian or avian species due to the lack of correspondence between the sequences in the GenBank. In some cases, it was not possible to obtain a consensus sequence probably due to the euryphagic behavior exhibited by the triatomines (37).

For R. pallescens, different mammalian blood sources, including opossum, anteater, sloth, rodent, and human, have been reported. Christensen, et al. (38) demonstrated that slightly more than half of the $R$. pallescens collected in houses and nearby palm trees and bird nests feed on humans in Panamá (38). Opossums, which are important reservoirs of $T$. cruzi in Panamá and Colombia, were the second most frequently selected host (38).

The community participation in entomological surveillance could be a good strategy to determine the presence of triatomines, establish infection indexes, and detect circulating DTUs and genotypes in the area. The community-based collection method allowed to report the presence of triatomines and infected triatomines for the first time in some dispersed rural settlements. The time (1520 days) between the collection and the delivery to the entomology technicians was a problem of this strategy. During this period of time, triatomines died and the specimen dried affecting further molecular procedures.

Our results revealed the presence of $T$. cruzi infected triatomines inside the dwellings and the predominance of $\mathrm{Tcl}_{\mathrm{DOM}}$, a $T$. cruzi DTU associated with Chagas disease in humans and cardiomyopathies in Colombia (35). We also concluded that $R$. pallescens, the most abundant vector species in the area, apparently feeds on mammalian blood. According to the literature, this species has an anthropophagic affinity, especially in rural areas (38). All these results together demonstrate that Chagas disease is a threat for the inhabitants of these five municipalities, especially in Moñitos and Sahagún dispersed rural settlements. It is necessary to implement entomological surveillance programs that incorporate the community-based collection component.

Finally, our results highlight the participation of local community members in entomological surveillance tasks and confirm that community-based collection is an excellent tool for monitoring non-domiciliated triatomines (20). All captured insects were Hemiptera, which shows that people from these five municipalities are aware of this important group of insects. 


\section{References}

1. Chagas C. Nova tripanozomiaze humana: estudos sobre a morfolojia e o ciclo evolutivo do Schizotrypanum cruzi n. gen., n. sp., ajente etiolojico de nova entidade morbida do homem. Mem Inst Oswaldo Cruz. 1909;1:159-18. https://doi.org/10.1590/S0074-02761909000200008

2. Teixeira A, Nitz N, Guimaro M, Gomes C, Santos-Buch C. Chagas disease. Postgrad Med J. 2006;82:788-98. https://doi.org/10.1136/pgmj.2006.047357

3. Jannin J, Villa L. An overview of Chagas disease treatment. Mem Inst Oswaldo Cruz. 2007;102 (Supl. 1):95-7. https://doi.org/10.1590/S0074-02762007005000106

4. Zingales B, Andrade SG, Briones MR, Campbell DA, Chiari E, Fernandes O, et al. A new consensus for Trypanosoma cruzi intraspecific nomenclature: Second revision meeting recommends Tcl to TcVI. Mem Inst Oswaldo Cruz. 2009;104:1051-4. https://doi.org/10.1590/S0074-02762009000700021

5. Zingales B, Miles M, Campbell D, Tibayrenc M, Macedo A, Teixeira M, et al. The revised Trypanosoma cruzi subspecific nomenclature: Rationale, epidemiological relevance and research applications. Infect Genet Evol. 2012;12:240-53. https://doi.org/10.1016/j. meegid.2011.12.009

6. Añez N, Crisante G, da Silva F, Rojas A, Carrasco H, Umezawa E, et al. Predominance of lineage I among Trypanosoma cruzi isolates from Venezuelan patients with different clinical profiles of acute Chagas disease. Trop Med Int Health. 2004;9:1319-26. https://doi.org/10.1111/j.1365-3156.2004.01333.x

7. Guhl F, Ramírez JD. Trypanosoma cruzi I diversity: Towards the need of genetic subdivision? Acta Trop. 2011;119:1-4. https://doi.org/10.1016/j.actatropica.2011.04.002

8. Guhl F, Aguilera G, Pinto N, Vergara D. Actualización de la distribución geográfica y ecoepidemiología de la fauna de triatominos (Reduviidae: Triatominae) en Colombia. Biomédica. 2007;27(Supl. 1):143-62. https://doi.org/10.7705/biomedica.v27i1.258

9. Rassi A Jr, Rassi A, Marcondes De Rezende J. American trypanosomiasis (Chagas disease). Infect Dis Clin North Am. 2012;26:275-91. https://doi.org/10.1016/j.idc.2012.03.002

10. Instituto Nacional de Salud. Enfermedad de Chagas. Fecha de consulta: 30 de enero de 2017. Disponible en: http://simposiovirologia.ins.gov.co/temas-de-interes/Paginas/chagas.aspx

11. Moncayo A, Silveira AC. Current epidemiological trends for Chagas disease in Latin America and future challenges in epidemiology, surveillance and health policy. Mem Inst Oswaldo Cruz. 2009; 104(supl. 1):17-30. https://doi.org/10.1590/S0074-02762009000900005

12. Zambrano P. Protocolo de vigilancia en salud pública: Chagas. Fecha de consulta: 14 de noviembre de 2016. Disponible en: http://simposiovirologia.ins.gov.co/lineas-de-accion/ Subdireccion-Vigilancia/sivigila/Protocolos\%20SIVIGILA/PRO\%20Chagas.pdf

13. Montilla M, Soto H, Parra E, Torres M, Carrillo P, Lugo L, et al. Infestación por triatominos en comunidades indígenas de Valledupar, Colombia. Rev Saúde Pública. 2011;45:773-80. https://doi.org/10.1590/S0034-89102011005000037

14. Cantillo O, Garcés E, Gómez A, Cortés L, Pereira A, Marcet P, et al. Eco-epidemiological study of an endemic Chagas disease region in northern Colombia reveals the importance of Triatoma maculata (Hemiptera: Reduviidae), dogs and Didelphis marsupialis in Trypanosoma cruzi maintenance. Parasit Vectors. 2015;22:482. https://doi.org/10.1186/s13071-015-1100-2

15. Instituto Nacional de Salud. Sistema Nacional de Vigilancia en Salud Pública-Sivigila. Fecha de consulta: 14 de noviembre del 2016. Disponible en:

http://www.portalsivigila.ins.gov.co/sivigila/reportes/pages/vigilancia.php

16. Departamento Administrativo Nacional de Estadística (DANE). Atlas estadístico. Fecha de consulta: 16 de noviembre de 2016. Disponible en: http://www. http://sige.dane.gov.co/atlasestadistico/

17. Sociedad Geográfica de Colombia. Departamento de Córdoba. Fecha de consulta: 14 de noviembre de 2016. Disponible en: http://www.sogeocol.com.co

18. Freire EE, Perfetti del Corral M. Pobreza Monetaria 2015: Córdoba. Fecha de consulta: 15 de noviembre de 2016. Disponible en:

http://www.dane.gov.co/index.php/estadisticas-por-tema/informacion-regional 
19. Salomon OD. Aspectos de prevención de la enfermedad de Chagas con participación de la comunidad. Fecha de consulta: 14 de noviembre de 2016. Disponible en: http://www.fac.org.ar/fec/chagas2/llave/md1/md103/salomon.htm

20. Dumonteil E, Ramírez-Sierra MJ, Ferral J, Euan-García M, Chávez-Núñez L. Usefulness of community participation for the fine temporal monitoring of house infestation by nondomiciliated triatomines. J Parasitol. 2009;95:469-71. https://doi.org/10.1645/GE-1712.1

21. Gómez-Núñez JC. Desarrollo de un nuevo método para evaluar la infestación intradomiciliaria por Rhodnius prolixus. Acta Cien Ven. 1965;16:26-31.

22. Angulo V, Esteban L. Nueva trampa para la captura de triatominos en hábitats silvestres y peridomésticos. Biomédica. 2011;31:264-68. https://doi.org/10.7705/biomedica.v31i2.301

23. Lent $\mathrm{H}$, Wygodzinsky P. Revision of the triatominae (Hemiptera, Reduviidae), and their significance as vectors of Chagas' disease. Bulletin of the American Museum of Natural History. New York: American Museum of Natural History; 1979. p. 389.

24. Weirauch C, Bérenger JM, Berniker L, Forero D, Forthman M, Frankenberg S, et al. An illustrated identification key to assassin bug subfamilies and tribes (Hemiptera: Reduviidae). Can J Art Iden. 2014;26:1-115.

25. Wincker P, Britto C, Borges J, Cardoso MA, Oelemann W, Morel CM. Use of a simplified polymerase chain reaction procedure to detect Trypanosoma cruzi in blood samples from chronic chagasic patients in a rural endemic area. Am J Trop Med. Hyg. 1994;51:771-7. https://doi.org/10.4269/ajtmh.1994.51.771

26. Virreira M, Torrico F, Truyens C, Alonso-Vega C, Solano M, Carlier Y, et al. Comparison of polymerase chain reaction methods for reliable and easy detection of congenital Trypanosoma cruzi infection. Am J Trop Med Hyg. 2003;68:574-82.

27. Piron M, Fisa R, Casamitjana N, López-Chejade P, Puig L, Vergés M, et al. Development of a real-time PCR assay for Trypanosoma cruzi detection in blood samples. Acta Trop. 2007;103:195-200. https://doi.org/10.1016/j.actatropica.2007.05.019

28. Souto RP, Fernandes O, Macedo AM, Campbell DA, Zingales B. DNA markers define two major phylogenetic lineages of Trypanosoma cruzi. Mol Biochem Parasitol. 1996;83:141-52. https://doi.org/10.1016/S0166-6851(96)02755-7

29. Villa LM, Guhl F, Zabala D, Ramírez JD, Urrea DA, Hernández DC, et al. The identification of two Trypanosoma cruzi I genotypes from domestic and sylvatic transmission cycles in Colombia based on a single polymerase chain reaction amplification of the spliced-leader intergenic region. Mem Inst Oswaldo Cruz. 2013;108:932-5. https://doi.org/10.1590/0074-0276130201

30. Falla A, Herrera C, Fajardo A, Montilla M, Vallejo GA, Guhl F. Haplotype identification within Trypanosoma cruzi I in Colombian isolates from several reservoirs, vectors and humans. Acta Trop. 2009;110:15-21. https://doi.org/10.1016/j.actatropica.2008.12.003

31. Sawabe K, Isawa H, Hoshino K, Sasaki T, Roychoudhury S, Higa Y, et al. Host-feeding habits of Culex pipiens and Aedes albopictus (Diptera: Culicidae) collected at the urban and suburban residential areas of Japan. J Med Entomol. 2010;47:442-50.

32. Rangel JO. Colombia Diversidad Biótica XI Patrones de la estructura y de la riqueza de la vegetación en Colombia. Bogotá: Instituto de Ciencias Naturales, Universidad Nacional; 2011. p. 485.

33. Zumaya-Estrada FA, Messenger LA, López-Ordóñez T, Lewis MD, Flores-López CA, Martínez-lbarra AJ, et al. North American import? Charting the origins of an enigmatic Trypanosoma cruzi domestic genotype. Parasit Vectors. 2012;5:226. https://doi.org/10.1186/1756-3305-5-226

34. Duque MC, Ramírez JD, Rendón LM, Guhl F. Evaluación de la variabilidad genética de aislamientos colombianos de Trypanosoma cruzi mediante marcadores microsatélites. Infectio. 2011;15:227-34. https://doi.org/10.1016/S0123-9392(11)70736-6

35. Ramírez JD, Duque MC, Montilla M, Cucunubá Z, Guhl F. Natural and emergent Trypanosoma cruzi l genotypes revealed by mitochondrial (Cytb) and nuclear (SSU rDNA) genetic markers. Exp Parasitol. 2012;132:487-94. https://doi.org/10.1016/j.exppara.2012.09.017

36. León C, Hernández C, Montilla M, Ramírez J. Retrospective distribution of Trypanosoma cruzi I genotypes in Colombia. Mem Inst Oswaldo Cruz. 2015;110:387-93.

https://doi.org/10.1590/0074-02760140402 
37. Zeledón R, Rabinovich JE. Chagas' disease: An ecological appraisal with special emphasis on its insect vectors. Annu Rev Entomol. 1981;26:101-33.

https://doi.org/10.1146/annurev.en.26.010181.000533

38. Christensen HA, de Vásquez AM. Host feeding profiles of Rhodnius pallescens (Hemiptera: Reduviidae) in rural villages of Central Panamá. Am J Trop Med Hyg. 1981;30:278-83. https://doi.org/10.4269/ajtmh.1981.30.278 